\title{
On the Indeterminacy Crisis: Critiquing Critical Dogma
}

\author{
Lawrence B. Solum $†$
}

\begin{abstract}
I am not thinking of these dogmas as determining men's opinions but rather as completely controlling the expression of all opinions. People will live under an absolute, palpable tyranny, though without being able to say they are not free. . . . For dogma is expressed in the form of an assertion, and is unshakable, but at the same time any practical opinion can be made to harmonize with it; admittedly more easily in some cases than in others. It is not a wall setting limits to what can be believed, but more like a brake which, however, practically serves the same purpose; it's almost as though someone were to attach a weight to your foot to restrict your freedom of movement. This is how dogma becomes irrefutable and beyond the reach of attack.
\end{abstract}

Ludwig Wittgenstein ${ }^{1}$

Critical legal scholarship challenges the liberal claim that modern western societies are characterized by "the rule of law." The liberal conception of the rule of law, critical scholars contend, serves to mystify and legitimate the legal system and thereby obscure the real issues behind individual cases as well as the real nature of the legal system. Frequently, the claim that legal rules are indeterminate is the starting point for such a critique of the rule of law. What I call the indeterminacy thesis goes roughly like this: the existing body of legal doctrines-statutes, administrative regulations, and court decisions-permits a judge to justify any result she desires in any particular case. Put another way, the idea is that a competent adjudicator can square a decision in favor of either side in any given lawsuit with the existing body of legal rules.

This article critiques the indeterminacy thesis as it has been developed in critical legal scholarship. Two assumptions related to the indeterminacy thesis are widely held by critical scholars. First, much critical scholarship assumes that the indeterminacy thesis al-

$\dagger$ Associate Professor of Law, Loyola Law School, Los Angeles, California. I owe thanks to Ken Anderson, Bob Benson, Don Brosnan, Sharon Lloyd, and Joe McCahery for comments on this essay. An earlier version was delivered to the course on Philosophy and Social Science at the Inter-University Center for Post Graduate Studies in Dubrovnik, Yugoslavia.

${ }^{1}$ Ludwig Wittgenstein, Culture and Value 28e (Peter Winch trans. 1980) (original emphasis). 
ways accurately describes legal phenomena. Second, critical scholarship frequently assumes that the indeterminacy thesis plays an important role in support of a related thesis, the mystification thesis-the claim that legal discourse conceals and reinforces relations of domination. ${ }^{2}$ I explore the problematic character of both of these critical claims and suggest that critical scholars have a long way to go in formulating indeterminacy as a workable proposition with real critical bite. Finally, I suggest that adherence to a strong view of indeterminacy is actually counterproductive to the program of critical scholarship.

\section{CRitical Scholarship: Indeterminacy and Mystification}

A wide variety of critical scholarship acknowledges and embraces the thesis that legal doctrine is indeterminate. ${ }^{3}$ To avoid speaking too generally of a large and diverse body of work, I begin with a catalog of the various contexts and familiar formulations in which the indeterminacy thesis has appeared in the literature.

Some critical scholarship explicitly addresses the indeterminacy thesis itself as a claim about law in general. An early piece by Duncan Kennedy, Form and Substance in Private Law Adjudication, offers a very cautious and limited observation about indeterminacy: some indeterminacy is inherent in any system of rules and exceptions, and a typical historical pattern of legal development involves the growth of indeterminacy in what begins as a determinate body of rules. ${ }^{4}$

Stronger forms of the thesis emerge in more recent critical scholarship. David Kairys writes:

The starting point of critical theory is that legal reasoning

2 Some members of the Conference on Critical Legal Studies no longer maintain, or have never maintained, either or both of these two claims. Viewing the output of the movement as a whole, however, I believe that these two claims about indeterminacy are characteristic of critical scholarship. Where possible, my illustrations of the thesis are taken from readily accessible sources-for example, the recent anthology of critical scholarship, David Kairys, ed., The Politics of Law: A Progressive Critique (1982), and the recent symposium in the Stanford Law Review, Critical Legal Studies Symposium, 36 Stan. L. Rev. 1-674 (1984). As will become apparent, my analysis draws from a broad spectrum of critical scholars. For a comprehensive bibliography of critical scholarship, see Duncan Kennedy and Karl E. Klare, A Bibliography of Critical Legal Studies, 94 Yale L. J. 461 (1984).

s Thus, I use the phrase "indeterminacy thesis" to refer broadly to the indeterminacy of authoritative legal materials of all sorts. One could distinguish various component theses-for example, legal rule indeterminacy and case law indeterminacy.

489 Harv. L. Rev. 1685, 1701 (1976). For Kennedy's current position, see Duncan Kennedy, Toward a Critical Phenomenology of Judging, in Allan C. Hutchinson and Patrick Monahan, eds., The Rule of Law: Ideal of Ideology 141 (1987) ("Critical Phenomenology"). 
does not provide concrete, real answers to particular legal or social problems. Legal reasoning is not a method or process that leads reasonable, competent, and fair-minded people to particular results in particular cases. . . . The ultimate basis for a decision is a social and political judgment incorporating a variety of factors, including the context of the case, the parties, and the substance of the issues. The decision is not based on, or determined by, legal reasoning. ${ }^{5}$

More elaborate articulations of the indeterminacy thesis as a general theory appear in recent articles by Joseph Singer, James Boyle, and Gary Peller. ${ }^{\circ}$

The indeterminacy thesis also plays a prominent role in critical scholarship focused on discrete legal topics. Recent critical analyses of contract law by Clare Dalton and Jay Feinman make use of indeterminacy. ${ }^{7}$ Critical approaches to constitutional law, including the freedom of speech, emphasize the indeterminacy of public law. ${ }^{8}$ The indeterminacy thesis is expounded in critical approaches to law and bureaucracy ${ }^{\ominus}$ and to a variety of other topics.

I will elaborate on the difference between what I call the "strong" and "weak" versions of the thesis in later parts of this article, where I will also argue that the thesis is deficient in several important respects. At this point, however, I want to be more concrete about the general thesis, not by examining its content, but by giving examples of specific techniques used by critical scholars to demonstrate that individual legal doctrines are indeterminate.

- David Kairys, Law and Politics, 52 Geo. Wash. L. Rev. 243, 244, 247 (1984). See also David Kairys, Legal Reasoning, in Kairys, ed., The Politics of Law 11, 15 (cited in note 2).

' Joseph William Singer, The Player and the Cards: Nihilism and Legal Theory, 94 Yale L. J. 1 (1984); James Boyle, The Politics of Reason: Critical Legal Theory and Local Social Thought, 133 U. Pa. L. Rev. 685 (1985); Gary Peller, The Metaphysics of American Law, 73 Cal. L. Rev. 1151 (1985).

2 Clare Dalton, An Essay in the Deconstruction of Contract Doctrine, 94 Yale L. J. 997 (1985); Jay M. Feinman, Promissory Estoppel and Judicial Method, 97 Harv. L. Rev. 678 (1984).

B As to constitutional law in general, see Mark V. Tushnet, A Note on the Revival of Textualism in Constitutional Theory, 58 So. Cal. L. Rev. 683 (1985); Mark V. Tushnet, Critical Legal Studies and Constitutional Law: An Essay in Deconstruction, 36 Stan. L. Rev. 623 (1984); Mark V. Tushnet, Following the Rules Laid Down: A Critique of Interpretivism and Neutral Principles, 96 Harv. L. Rev. 781 (1983).

As to free speech in particular, see David Kairys, Freedom of Speech, in Kairys, ed., The Politics of Law 140, 160-61 (cited in note 2) ("[S]ince precedents and reasoning can be distinguished, modified, or discarded, they do not require any particular rule or result. . . . [T] he law merely provides a variety of bases for justifying choices made on other grounds.").

- Gerald E. Frug, The Ideology of Bureaucracy in American Law, 97 Harv. L. Rev. 1276, 1292 (1984) ("Legal doctrine thus provides a justification for both a particular course of action and its opposite."). 
Critical scholars often try to demonstrate that a given body of legal doctrine is indeterminate by showing that every so-called legal rule is opposed by a counterrule. Because the rule and the counterrule support opposing results, the authoritative legal materials, taken as a whole, fail to provide determinate outcomes in any given case. Duncan Kenndy provides a concise example from the field of contract law:

In [some] situations, a "rule" that appears to dispose cleanly of a fact situation is nullified by a counterrule whose scope of application seems to be almost identical. Agreements that gratuitously increase the obligations of one contractual partner are unenforceable for want of consideration. But, such agreements may be binding if the judge can find an implied rescission of the old contract and the formation of a new one incorporating the unilaterally onerous terms. The realists taught us to see this arrangement as a smokescreen hiding the skillful judge's decision as to duress in the process of renegotiation, and as a source of confusion and bad law when skill was lacking. ${ }^{10}$

Another technique is to demonstrate that application of a doctrinal category of distinction is in fact based on a circular reasoning process. The public/private distinction, for example, figures in a wide variety of legal contexts, from torts and contracts to labor law and constitutional law. ${ }^{11}$ Kennedy argues that no agreed upon conception of this distinction guides judicial choices; rather, the distinction is invoked to justify a decision that is in fact reached on other grounds. ${ }^{12}$

A third technique used to demonstrate indeterminacy involves revealing that a seemingly determinate legal rule is in fact "open textured"- that it allows the judge to perform an ad hoc balancing of a number of factors. Again, Kennedy provides an example:

10 Kennedy, 89 Harv. L. Rev. at 1700 (cited in note 4) (original emphasis). For the classic example of such an attack by a legal realist, see Karl N. Llewellyn, Remarks on the Theory of Appellate Decision and the Rules or Canons About How Statutes Are To Be Construed, 3 Vand. L. Rev. 395 (1950).

1 See Karl E. Klare, The Public/Private Distinction in Labor Law, 130 U. Pa. L. Rev. 1358 (1982); Girardeau A. Spann, Deconstructing the Legislative Veto, 68 Minn. L. Rev. 473 (1984).

12 Duncan Kennedy, The Stages of the Decline of the Public/Private Distinction, 130 U. Pa. L. Rev. 1349 (1982). Girardeau Spann employed a similar technique, which he calls "analytic spin," to the separation of powers doctrine in constitutional law. Spann, $68 \mathrm{Minn}$. L. Rev. at 520 (cited in note 11). 
[L]egal directives that looked general and formally realizable were in fact indeterminate. Take, for example, the "rule" that a contract will be rescinded for mutual mistake going to the "substance" or "essence" of the transaction, but not for mistakes as to a "mere quality or accident," even though the quality or accident in question was the whole reason for the transaction. We have come to see legal directives of this kind as invitations to sub rosa balancing of the equities. Such covert standards may generate more uncertainty than would a frank avowal that the judge is allocating a loss by reference to an open textured notion of good faith and fair dealing. ${ }^{13}$

Of course, rules that are open textured on their face, such as the equal protection and due process clauses of the Constitution, are-at least when considered in isolation-similarly indeterminate.

Finally, a number of critical scholars have found a source of indeterminacy not in the legal rules themselves, but in the public policies or theories that justify the rules and guide their application. For example, Kennedy has argued that cost-benefit analysis, a tool of utilitarianism, does not produce determinate results in particular cases. ${ }^{14}$ In addition, critical scholars often claim that indeterminacy results when the legal doctrine attempts to incorporate competing rationales. A continual and indeterminate conflict in contract law, for instance, is said to be the result of the law's attempt to reconcile the fundamentally contradictory principles of autonomy and community. ${ }^{15}$

I pause now to examine this argument in some detail. It is easy to agree that existing legal rules are not fully determined by any unified and consistent social theory. Even if we had a fully satisfactory theory justifying the broad outlines of the modern state, it would be hard to argue that any such theory required a particular set of legal rules, much less the precise set of rules we have now. However, it does not follow from this admission that critical scholars have made out a case for complete indeterminacy of justification. Some specific legal rules may necessarily follow from a broad social theory; many legal rules may be incompatible with a given theory.

1s Kennedy, 89 Harv. L. Rev. at 1700 (cited in note 4).

${ }^{14}$ Duncan Kennedy, Cost-Benefit Analysis of Entitlement Problems: A Critique, 33 Stan. L. Rev. 387 (1981).

15 Jay M. Feinman, Critical Approaches to Contract Law, 30 U.C.L.A. L. Rev. 829, 847 (1983). 
Moreover, indeterminacy of justification does not entail indeterminacy in a set of legal rules. ${ }^{16} \mathrm{~A}$ number of competing theories could be used to justify or critique a wide range of legal doctrines, while the legal doctrines themselves nonetheless would constrain the outcome of particular cases. ${ }^{17}$ For example, one could make consequentialist arguments for and against the doctrine of promissory estoppel, while the doctrine itself remained determinate in application. Of course, if (as is often the case) the justification for a rule is used to guide its application, indeterminacy of justification will lead to greater indeterminacy of legal outcomes.18

So far I have only described some of the common arguments used to suggest that legal rules are indeterminate. But what exactly follows from this? Generally, the critical force of the indeterminacy thesis is thought to derive from its relationship to the mystification thesis-the view that legal rules mystify structures of domination.

The notion that legal discourse veils relationships of domination is central to a wide range of critical scholarship. Duncan Kennedy writes that Blackstone's Commentaries are "an instrument of apology -an attempt to mystify both the dominators and the dominated by convincing them of the 'naturalness,' the 'freedom' and the 'rationality' of a condition of bondage." 19 Similarly, Peter Gabel and Jay Feinman write of contract law, "The central point to understand . . . is that contract law today constitutes an elaborate attempt to conceal what is going on in the world."20 Richard Abel writes of the law of torts, "[Tort law's] focus on superficial equality hides the persistence of numerous invisible inequalities."21 Karl Klare writes of labor law, "The latent value system of labor law is, in short, a legitimating ideology that reinforces the dominant institutions and hegemonic culture of our society."22 David Kairys

16 Indeterminacy of justification poses special problems for Ronald Dworkin's theory of legal interpretation, which links the meaning of a legal text to its justification. See Ronald Dworkin, Law's Empire 225-75 (1986). For a discussion of this issue, see Andrew Altman, Legal Realism, Critical Legal Studies, and Dworkin, 15 Phil. and Pub. Affairs 205 (1986).

17 Dworkin, Law's Empire at 274-75 (cited in note 16).

18 For example, see Steelworkers v. Weber, 443 U.S. 193 (1979) (in light of its purpose, Title VII's prohibition of racial discrimination must be read to allow affirmative action in some circumstances).

19 Duncan Kennedy, The Structure of Blackstone's Commentaries, 28 Buff. L. Rev. 205, 210 (1979).

${ }^{20}$ Peter Gabel and Jay M. Feinman, Contract Law as Ideology, in Kairys, ed., The Politics of Law 172, 183 (cited in note 2).

${ }_{23}$ Richard L. Abel, Torts, in Kairys, ed., The Politics of Law 185, 189 (cited in note 2).

22 Karl E. Klare, Critical Theory and Labor Relations Law, in Kairys, ed., The Politics of Law 65, 73 (cited in note 2). 
writes of the first amendment, "The ideology of free speech . . . is used to validate and legitimize existing social and power relations and to mask a lack of real participation and democracy."23 And on the role of the doctrine of stare decisis, Kairys writes that it has often "provided a falsely legitimizing justification for a decision that is ultimately social and political" and "serves to disguise enormous discretion." 24

As H. L. A. Hart has observed, the mystification thesis has been a prominent feature of Anglo-American writing about the law at least since the time of Jeremy Bentham. ${ }^{25}$ Indeed, the mystification thesis falls squarely within the tradition of critique of ideology associated with Marx $^{28}$ and the Frankfurt School. ${ }^{27}$

The mystification thesis involves a number of interrelated claims about the ideological character of legal discourse. John Thompson suggests three characteristic methods by which ideological discourse can sustain relationships of domination: legitimation, dissimulation, and reification. ${ }^{28}$ Critical legal scholars have made claims that the law mystifies through all three methods. The first method, legitimation, is the process by which systems of domination seek to cultivate belief in their legitimacy by appealing to rational, traditional, or charismatic grounds. ${ }^{29}$ The notion that legal discourse legitimizes existing institutions is common in critical scholarship. Peter Gabel and Paul Harris, for example, argue that legal discourse legitimizes the existing order through an appeal to tradition and charisma: the law channels social conflict "into public settings that are heavily laden with ritual and authoritarian symbolism." 30 2).

${ }^{23}$ Kairys, Freedom of Speech, in Kairys, ed., The Politics of Law at 164 (cited in note

24 Kairys, Legal Reasoning, in Kairys, ed., The Politics of Law at 15, 14 (cited in note 2).

${ }^{25}$ See H. L. A. Hart, The Demystification of the Law, in H. L. A. Hart, Essays on Bentham 21, 21-22 (1982).

${ }^{26}$ See, e.g., Jon Elster, Making Sense of Marx ch. 8 (1985).

${ }^{27}$ See, e.g., Raymond Geuss, The Idea of a Critical Theory: Habermas and the Frankfurt School (1981).

28 John B. Thompson, Studies in the Theory of Ideology 131 (1984). Thompson does not suggest that the three methods exhaust the means by which ideologies perpetuate hierarchy. Id.

29 For a general discussion of the process of legitimation, see Max Weber, Politics as a Vocation, in From Max Weber 77, 78-83 (H. H. Gerth and C. Wright Mills trans. 1958).

so Peter Gabel and Paul Harris, Building Power and Breaking Images: Critical Legal Theory and the Practice of Law, 11 N.Y.U. Rev. L. \& Soc. Change 369, 372 (1982). For example, "participants are brought before a judge in a black robe who sits elevated from the rest." Id. 
The second method is dissimulation: relations of domination that serve the interest of a particular group at the expense of others are concealed. Wythe Holt argues that the apparent neutrality of the law masks "tilt"- the bias of the law in favor of the interests of the ruling elite. ${ }^{31}$ In a similar vein, Gabel writes, "The objective of the Supreme Court is to pacify conflict through the mediation of a false social-meaning system, a set of ideas and images about the world which serve today as the secular equivalent of religious ideology in previous historical periods."32

The third method of mystifying the law is reification: the representation of something abstract as a material thing. Critical scholars contend that legal discourse engages in reification by representing a transitory, historical, or contingent state of affairs as if it were permanent and natural. Gary Peller writes:

[J]udges' assertion of access to the determinate and neutral meaning of social events actually rested on the institutionalization of contingent and socially created metaphors. These metaphors constructed the "reality" that within the legal discourse was supposed to exist out there, in social relations themselves. This reification of representational practice denied the manner in which legal discourse actually constructed the world it purported to represent. ${ }^{33}$

Reification reinforces the status quo by making political choices appear to be dictated by nature itself.

With this brief sketch of the mystification thesis in mind, I turn to the relationship between indeterminacy and mystification. Critical scholars argue that indeterminacy is linked to mystification in two related ways. First, some claim that the appearance of determinacy in the application of legal rules is itself an example of legitimizing legal discourse. The notion that legal rules produce determinate results reinforces the claim that the law is a neutral mechanism of dispute resolution. As Joseph Singer asserts, "Determinacy is necessary to the ideology of the rule of law, for both theorists and judges. It is the only way judges can appear to apply the law rather than make it." expresses the contention that "the law provides only a wide and

31 Wythe Holt, Tilt, 52 Geo. Wash. L. Rev. 280, 284-85 (1984).

32 Peter Gabel, The Mass Psychology of the New Federalism: How the Burger Court's Political Imagery Legitimizes the Privatization of Everyday Life, 52 Geo. Wash. L. Rev. 263, 265 (1984).

ss Peller, 73 Cal. L. Rev. at 1214 (cited in note 6).

s* Singer, 94 Yale L. J. at 12 (cited in note 6). 
conflicting variety of stylized rationalizations from which courts pick and choose." specific instance of mystification.

Critical scholarship also recognizes a second link between indeterminacy and mystification. The legal system reinforces relations of social and economic domination while retaining the appearance of neutrality and autonomy. But, according to the critics, the independence of the legal system is more apparent than real. As Kairys puts it, the outcome in a particular case is determined by "[s]ocial and political judgments about the substance, parties, and context of a case." Thus, judges' "backgrounds, socialization, and experiences," which bias them in favor of the existing power structure, "result in a patterning" of legal decisions. "This is the great source of the law's power: it enforces, reflects, constitutes, and legitimizes dominant social and power relations without a need for or the appearance of control from outside and by means of social actors who largely believe in their own neutrality and the myth of legal reasoning."

\section{ThE "Strong" Indeterminacy ThESIS}

Critical scholars frequently defend against criticism of the indeterminacy thesis by saying that the challenged thesis is not the real indeterminacy thesis. Joseph Singer recently wrote, "Everyone is confused about what Critical Legal Scholars mean when we say that law or rights or legal theory is indeterminate." ${ }^{\text {"37 }}$ It is clear to me that critical scholars do not speak with a single voice and that there are several different versions of the indeterminacy thesis. I will begin unraveling the various stands of the indeterminacy thesis by making a distinction between its "strong" and "weak" versions, discussing the "strong" version in this section and the "weak" version in the next.

The strong version of the indeterminacy thesis claims that all cases are "hard" cases or, more precisely, that in every case any result can be derived from the preexisting legal doctrine. Although some critical scholars have explicitly rejected the strong indeterminacy thesis, contemporary critical legal scholarship still abounds in

ss David Kairys, Introduction, in Kairys, ed., The Politics of Law at 3 (cited in note 2).

${ }^{36}$ Id. at 3, 5, 5. These questions-how legal doctrine can be determined by underlying social forces, and how the apparent autonomy of legal reasoning can be illusory-are far more complex than these few quotes suggest. For an excellent introduction to these issues, see Hugh Collins, Marxism and Law (1982).

${ }^{37}$ Singer, 94 Yale L. J. at 10 (cited in note 6). 
assertions that the law is radically indeterminate. In a recent article, for example, Clare Dalton writes, "doctrinal inconsistency necessarily undermines the force of any conventional legal argument, and ... opposing arguments can be made with equal force. . . . [L]egal argumentation disguises its own inherent indeterminacy. ... [L]egal doctrine is unable to provide determinate answers to particular disputes." "s8 Giradeau Spann also affirms the strong version of the thesis: "[T]he characteristics of [legal] doctrine that made it indeterminate in Chadha will make it indeterminate in all other cases as well." Lis Likewise, Charles Yablon claims that "[ $\mathrm{t}] \mathrm{he}$ experienced advocate knows that the doctrinal regime is sufficiently complex that there will always be some set of authoritative materials which, through skillful manipulation of the level of specificity and characterization of the facts, he can declare to be "controlling' of the case at bar" in a way that supports "any position a client wishes to maintain."

\section{A. The Argument From Easy Cases}

The strong thesis is difficult to defend; even a single example of a case whose results are determined by the body of legal doctrines taken as a whole refutes Dalton's ambitious claim that "doctrinal inconsistency necessarily undermines the force of any conventional legal argument." One is tempted to prove the existence of one determined case in the same manner G. E. Moore sought to demonstrate the existence of an external world: ${ }^{41}$

This first paragraph of this essay does not slander Gore Vidal. Thus, I prove that one legal rule has at least one determinate application.

Of course, this argument from easy cases $^{42}$ can lapse into facile ref-

ss Dalton, 94 Yale L. J. at 1007 (cited in note 7) (emphasis added).

30 Spann, 68 Minn. L. Rev. at 528 (cited in note 11). I.N.S. v. Chadha, 462 U.S. 919 (1983), held that a statute giving Congress the power to veto adjudicatory action by an administrative agency-specifically, the Immigration and Naturalization Service-was unconstitutional.

40 Charles M. Yablon, The Indeterminacy of the Law: Critical Legal Studies and the Problem of Legal Explanation, 6 Cardozo L. Rev. 917, 918, 917-18 (1985).

${ }^{41}$ G. E. Moore, Proof of an External World, in G. E. Moore, Philosophical Papers 127 (1959). Moore offered an example of his proof: "if I can prove that there exist now both a sheet of paper and a human hand, I shall have proved that there are now "things outside of us." "Id. at 145.

12 For extended versions of this argument, see Kenney Hegland, Goodbye to Deconstruction, 58 So. Cal. L. Rev. 1203 (1985); Frederick Schauer, Easy Cases, 58 So. Cal. L. Rev. 399 (1985). 
utation. Indeed, an almost unlimited number of easy cases come to mind: walking one's dog does not violate the antitrust laws; smoking a cigarette does not offend the constitutional prohibition against third-term presidencies. But how easy an "easy" case is depends on how one defines "case." If a "case" is any claim that some example of human conduct violates a particular legal rule, these examples refute strong indeterminacy. However, if a "case" is a dispute between any two or more parties, the refutation becomes a bit harder. Walking one's dog might, depending on the facts and the law, involve a violation of laws against jaywalking or leaving animal excrement on the sidewalk. Likewise, smoking in a public area might violate some legal rule. Critical scholars might be tempted to defend the strong indeterminacy thesis by pointing out that additional facts could be added to the description of any hypothetical situation in order to implicate some legal rule. This defense is self-defeating, however. The need to invent additional facts demonstrates that the law is determinate. If anything is indeterminate, it is the content of the hypothetical case.

Nonetheless, it is not difficult to imagine easy cases where a particular action clearly does not violate any legal rule. If a homeowner eats ice cream in the privacy of her home, it will not give rise to any legal action. From jaywalking to murder and from valid contracts to intentional torts, easy cases abound. Because the strong indeterminacy thesis denies that such easy cases exist, that version of the thesis is simply wrong.

Many critical scholars will probably find this conclusion too hasty. How easy an easy case is also depends on how one defines "easy." While it is highly unlikely that eating ice cream in the privacy of one's own home will violate some legal rule, it is not "impossible" in every sense of the concept of possibility. This residual uncertainty is the basis for three lines of defense for the strong indeterminacy thesis. I will critique each in detail.

\section{B. Internal Skepticism}

The first line of defense for the strong thesis relies on conventional legal argumentation. The "internal skeptic" takes a so-called easy case, and attempts to demonstrate that it is actually a hard case. This skepticism is "internal" to the practice of law in that it is premised upon the acceptance by at least some judges and lawyers of the arguments offered to demonstrate that results in an 
"easy" case are really indeterminate. ${ }^{43}$ The rhetoric about easy cases and hard cases is useless unless we first flesh out exactly what is meant by "easy" and "hard" cases and by "indeterminacy." The distinctions between determinacy, indeterminacy, and a third concept-_underdeterminacy"-can be explained by considering the relationship between two sets of possible results of a given legal dispute. The first set consists of all imaginable results-the set of all the various orders that a judge could issue, however ridiculous or improbable. The second set consists of results that can be squared with the law-the set of all legally reasonable outcomes. "Law" means the legal materials taken as whole, including constitutions, statutes, and case law. On this basis, I offer the following definitions:

- The law is determinate with respect to a given case if and only if the set of results that can be squared with the legal materials contains one and only one result.

- The law is indeterminate with respect to a given case if and only if the set of results in the case that can be squared with the legal materials is identical with the set of all imaginable results.

- The law is underdeterminate with respect to a given case if and only if the set of results in the case that can be squared with the legal materials is a nonidentical subset of the set of all imaginable results. ${ }^{44}$

These definitions mark the distinctions between determinacy, indeterminacy, and underdeterminacy in a rigorous and formal way. The distinctions can be drawn more loosely in terms of "rulebound," "unbound," and "rule-guided" decisions. A decision is rule-bound if and only if a single outcome is consistent with the law. A decision is unbound if and only if the law does not place any limit on the range of possible results. A decision is rule-guided if and only if the outcome must be chosen on grounds other than the law itself-for example, on grounds of policy, principle, or even personal preference-from a range of possible results that are consistent with and limited by the law. The main point of these definitions is that if the law is not determinate with respect to a given

43 The distinction between internal and external legal skepticism is made in Dworkin, Law's Empire at 78-86 (cited in note 16). External skepticism proceeds from a perspective outside the practice of law. See also Kennedy, Critical Phenomenology at 164-66 (cited in note 4) (relying on a similar distinction).

14 By nonidentical subset, I mean that the subset excludes some results that were included in the set of all imaginable outcomes. 
case, it may be either underdeterminate or indeterminate.

We also should consider precisely why some cases are considered "hard." I offer two related formulations of the concept of a "hard case":

- Cases are "hard" when they are underdeterminate in a way such that the judge must choose among legally acceptable results that include outcomes that constitute victory (or loss) for each litigant, or various combinations of victory (or loss) for all parties to the litigation. ${ }^{45}$

- Hard cases are those in which the judge's choice among the set of legally acceptable results will substantially affect a significant practical interest of the litigants.

The main point of these formulations is that a case need not be completely indeterminate to be hard; cases that are underdeterminate can also be hard.

One oft-used example of an "easy" case that is claimed to be indeterminate is the constitutional rule that the president must be at least thirty-five years of age. To demonstrate that even such a crystal clear rule is indeterminate, Giradeau Spann argues that (1) the rule should be viewed in the wider context of the principle that it represents; (2) this principle may be that only mature persons may be president; and therefore (3) a court could rule that a precocious thirty-four year-old may assume the office. ${ }^{46}$

Spann's argument, however, confuses underdeterminacy with indeterminacy. Even if Spann's premises are acceptable to some practitioners and his conclusion follows, he has not demonstrated that the complete body of constitutional doctrine on qualifications for presidential officeholders is wholly indeterminate. Rather, what follows is that the doctrine-defined to encompass the constitutional text and Spann's hypothetical maturity principle -underdetermines the result. Even if a precocious thirty-four-year-old could become president, it does not also follow that a very immature eleven-year-old could. Spann has recharacterized the rule in such a way that it still constrains the results in particular cases. Although the constraint will be different and looser than some might first have imagined, there still remains a constraint.

\footnotetext{
is I am not taking a stand here on the question whether the judge has discretion in a "strong" sense or whether her choice is further constrained by considerations of principle. See Ronald Dworkin, Taking Rights Seriously 31-39 (1977) (judges' choices should be constrained by principle).

45 Spann, 68 Minn. L. Rev. at 532-33 (cited in note 11).
} 
This confusion between indeterminacy and underdeterminacy is also reflected in Duncan Kennedy's definition of formalism in his early essay, Legal Formality: "The essence of rule application, as I have defined it above, is that it is mechanical. The decision process is called rule application only if the actor resolutely limits himself to identifying those aspects of the situation which, per se, trigger his response." Ki Kennedy has defined rule application in such a way that only a completely determined decision will count as a decision that is not indeterminate. The difficulty with this definition is that legal rules (or, more broadly, doctrines) can significantly constrain outcomes even if they do not mechanically determine them.

My general argument against the internal skeptic's defense is that underdeterminacy is not the same as indeterminacy and that a case need not be indeterminate to be hard. With all this in mind, I can agree with critical scholars that there are some cases that appear easy on their surface but are actually hard. But the internal skeptics believe that by demonstrating that easy cases are hard cases, they have also demonstrated that the law is indeterminate. At this stage in the argument, I part company with these advocates of indeterminacy.

For two principal reasons, the internal skeptic cannot demonstrate that all law is indeterminate through conventional legal argumentation. The first reason is conceptual: if a decision is not determinate, it does not follow that it is also not underdeterminate and, therefore, indeterminate. Neither does it follow that because a case is hard, it is indeterminate. Even if all seemingly easy cases were actually hard cases, it would not follow that the law is indeterminate with respect to all these cases-although it would follow that the law is less determinate than we might have thought. Hard cases can be very hard, even if their results are not completely indeterminate. I submit further that even the hardest of hard cases are merely underdetermined by the law, not indeterminate. But I defer discussion of this point until later in this essay.

The second reason internal skepticism cannot prove complete indeterminacy is rooted in the standards implicit in the practice of acceptable legal argument: there are at least some very easy cases that are completely determinate. For example, if I were sued by Gore Vidal for slander on the basis of the first paragraph of this

472 J. Legal Stud. 351, 359 (1973) (original emphasis). See also Kennedy, Critical Phenomenology at 150 (cited in note 4) (assuming that "determination of the outcome" must result from "a process of legal argument that can only be done in one way"). 
article, the only possible outcome would be a verdict for me. A skeptic might respond that it is possible to think of an argument suggesting that I should lose the case, or that the judge could simply rule against me without explanation. But it is simply incredible to say that any such argument or arbitrary ruling would be considered acceptable by the legal profession. That is, this sort of defense of indeterminacy is not internal to the law. It may, however, have some critical bite-a matter I turn to in the following discussions of external skepticism and the epiphenomenalist defense.

\section{External Skepticism}

Since internal skepticism cannot demonstrate that all legal doctrine is indeterminate, many advocates of the strong indeterminacy thesis turn to some form of "external" skepticism. That is, they become skeptical about the determinacy of language in general, not just the language of legal rules. The legal realist Felix Cohen seems to have made this sort of a claim: "Every [judicial] decision is a choice between different rules which logically fit all past decisions but logically dictate conflicting results in the instant case." 48 Cohen seems to argue that no matter what the legal rules appear to be, alternative formulations of the rules are always available in a given case that are consistent with all past decisions, but yield opposing results.

Unless there is something very special about legal rules, ${ }^{49}$ this defense of the strong indeterminacy thesis must entail the claim that our language is simply not up to the task of formulating rules that have determinate applications. Defenders of the indeterminacy thesis have put forward two types of philosophical and linguistic arguments to support this rather grand conclusion.

1. The rule-skeptic's defense. Sometimes defenders of the indeterminacy thesis adopt a strong form of "rule-skepticism."

48 Felix Cohen, The Ethical Basis of Legal Criticism, 41 Yale L. J. 201, 216 (1931).

10 Of course, some critical scholars do claim that there is something very special about legal rules. I will consider the argument that indeterminacy reflects a "contradiction" in the liberal state below, at notes 65-72 and accompanying text.

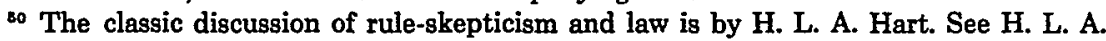
Hart, The Concept of Law ch. 7 (1961). The neglect of this text by serious adherents of the indeterminacy thesis is curious. James Boyle considers Hart's treatment, but his approach misunderstands Hart's application of the Wittgensteinian view of language to the problem of rule-skepticism: Boyle equates the notion of a paradigm case, or core application of a rule, with an essentialist theory of language. Boyle, $133 \mathrm{U}$. Pa. L. Rev. at 711-12 (cited in note 6). Nothing could be further from Hart's intent. See Hart, The Concept of Law at 12324 (cited in this note). 
Mark Tushnet has suggested, for example, that the indeterminacy thesis is rooted in a skeptical argument ${ }^{51}$ that is commonly supposed to have been made by Wittgenstein..$^{52}$ As I understand it, the critical version of rule-skepticism is the argument that one can always come up with a perfectly plausible interpretation of any rule, including legal rules, such that any particular behavior can be seen as either following or not following the rule. The claim is that as far as the rules are concerned, "Anything goes!"

In answer to Tushnet, Frank Michelman gives a lucid summary of the argument and a standard refutation:

From Wittgenstein we learned that a set of instructions can never finish explaining how itself is to be read; the signpost on the road fails to tell us whether to go in the direction of the point or the butt. The Wittgensteinian lesson, however, does not end there. It goes on to insist that judgments of error, mistake, and incompetency in the use of rules are nonetheless possible within a practice, a language-game, or a form of life. One can say, for example, that a traveler striking off in the direction of the butt-end of a road sign has failed to read the sign correctly. ${ }^{\text {ss }}$

The radical nature of the rule-skepticism Tushnet invoked can best be understood by giving an example a bit different from those Wittgenstein used to illustrate his skeptical paradox in the Philosophical Investigations. ${ }^{54}$ Consider a traffic code provision that requires a driver of a motor vehicle to stop at a red light. It is impossible to spell out fully, in advance, the meaning of the rule. For

s1 Tushnet, 58 So. Cal. L. Rev. at 688 n.24 (cited in note 8); Mark Tushnet, Legal Scholarship: Its Causes and Cure, 90 Yale L. J. 1205, 1217 (1981). James Boyle seems to hold a similar view, although he makes it less explicit than Tushnet. Boyle, 133 U. Pa. L. Rev. at 695 n.28, 708-20 (cited in note 6). Duncan Kennedy criticizes a version of ruleskepticism in a recent essay. Kennedy, Critical Phenomenology at 164-65 (cited in note 4).

${ }^{82}$ For Wittgenstein's version of the argument, see Ludwig Wittgenstein, Philosophical Investigations II 139-201 (G. E. M. Anscombe trans. 3d ed. 1958). For a recent exposition, see Saul Kripke, Wittgenstein On Rules and Private Language (1982). For criticism of Kripke's interpretation of Wittgenstein and of Kripke's own argument, see G. P. Baker and P. M. S. Hacker, Skepticism, Rules and Language (1984). Rule-skepticism has generated considerable controversy among philosophers. I want to disclaim any representation that the version of rule-skepticism that $I$ reconstruct on behalf of legal rule-skeptics is anything but a remote cousin of Wittgenstein's argument or even Saul Kripke's reconstruction of that argument. For a critical discussion of the use of nihilist philosophy by legal rule skeptics, see John Stick, Can Nihilism be Pragmatic?, 100 Harv. L. Rev. 332 (1986).

s3 Frank I. Michelman, Politics as Medicine: On Misdiagnosing Legal Scholarship, 90 Yale L. J. 1224, 1227 (1981).

st Wittgenstein uses the example of continuing a mathematical series. See Philosophical Investigations II 143-240 (cited in note 52). 
example, what does "motor vehicle" mean? Suppose that in a routine traffic case, the alleged violation of this rule was committed on a Tuesday by someone driving a blue Mercedes. It is logically possible that blue Mercedes, by definition, are not "motor vehicles" on Tuesdays, but rather something else, say, "molar feelicles." Even if one gives a rule defining the term "motor vehicle," say, "motor vehicles' are wheeled, self-propelled transportation devices," it is logically possible that "wheeled" doesn't refer to objects with the round things at the end of the axles of blue Mercedes on Tuesdays. Such things, we might say, are "whooled," not "wheeled."" A portion of Wittgenstein's argument can be interpreted as demonstrating that the rule-skeptic will never run out of such skeptical possibilities.

But the difficulty with appealing to Wittgenstein's skeptical paradox is that it costs the indeterminacy thesis its critical bite. Wittgenstein makes the following observation:

This was our paradox: no course of action could be determined by a rule, because every course of action can be made out to accord with the rule. The answer was: if everything can be made out to accord with the rule, then it can also be made out to conflict with it. And so there would be neither accord nor conflict here. ${ }^{58}$

Thus, we may admit the paradox but reject its significance because it has no consequences for human conduct. Like other skeptical paradoxes, it has no existential force. As Saul Kripke puts it, "It holds no terrors in our daily lives."

My argument, therefore, relies on the distinction between logical and practical possibility. This distinction can be illuminated by a brief discussion of an analogous problem with epistemological skepticism. An epistemological skeptic might claim that we can never really know anything. An anti-skeptic might respond with an

os Note the resemblance to Nelson Goodman's "new riddle of induction" and his famous "grue." See Nelson Goodman, Fact, Fiction and Forecast ch. 3 (1955) "Grue" is a hypothetical color that is used to describe emeralds, all of which discovered up to today are green, but some of which discovered in the future might be blue. Grue is green today, but green or blue in the future. All that we know today confirms both the prediction "all emeralds are green" and the prediction "all emeralds are grue." We could similarly hypothesize an infinite number of predictions about the possible colors of emeralds, all confirmed by current knowledge, leaving us "with the intolerable result that anything confirms anything." Id. at 73-74. See also Tushnet, 58 So. Cal. L. Rev. at 688 n.24 (cited in note 13) (remarking on connection between legal indeterminacy and Goodman's new riddle of induction).

${ }^{8 B}$ Wittgenstein, Philosophical Investigations II 201 (cited in note 52).

${ }_{87}$ Kripke, Wittgenstein On Rules at 87 (cited in note 52). 
example of an "easy case" of knowledge: you know that you are currently sitting in a chair and reading this peculiar article. The skeptic might respond by raising a skeptical possibility: for all you know you are only a brain in a vat being manipulated by an evil scientist to think you are sitting and reading this essay, when in fact you are doing neither of these things. ${ }^{88}$

Very roughly, it is my view that rule-skepticism can be shown to be toothless for the same reason that this sort of epistemological skepticism is toothless: worrying about being a brain in a vat will not have any effect on what you do. Likewise, worrying about ruleskepticism will not have any effect on the way cases are decided. The skeptical possibilities invoked by both rule-skepticism and epistemological skepticism are not practical possibilities, and only practical possibilities affect the way one acts.

This is not to say that there is no point to rule-skepticism. Rule-skeptics are quite right to insist that nothing about verbal formulations of rules requires or guarantees that they be applied in a particular, determinate fashion. Tushnet appreciates this point when he notes that expectations about easy cases "are socially constructed rather than inherent, even to some small degree, in the verbal formulations" of the legal rules. ${ }^{88}$ Legal rules in particular, like languages in general, develop meaning in a social context. Because of the truth of this observation, critical scholars are correct when they claim that there is a "possibility" that the legal rules will change meanings if the social context changes dramatically; nothing magical about the verbal formulation of legal rules excludes such a possibility.

However, the question we should ask is whether this possibility creates the sort of indeterminacy that has existential force. Does the possibility of legal rules changing in response to changes in society "hold terrors in our daily lives"? As far as the sort of skeptical possibilities needed to make a case for the strong indeterminacy thesis, the answer to this question is clearly "No."

But the lack of immediate, practical implications could be seen as giving a different sort of critical bite to the rule skeptic's defense of strong indeterminacy. Kripke suggests that Wittgen-

Bs For a classic retelling of the brain in a vat story, see Hilary Putnam, Reason, Truth and History 5-8 (1981). The grandfather of such skeptical possibilities is, of course, Descartes' evil demon. See Rene Descartes, First Meditation: Concerning Things that Can Be Doubted, reprinted in Rene Descartes, Philosophical Essays 75, 80 (Laurance J. Lafleur trans. 1964).

so Tushnet, 58 So. Cal. L. Rev. at 688 n.24 (cited in note 8). 
stein's skeptical paradox may be resolved using the notion of "community":"00 our actual community does agree on how many rules are applied-including, for example, the red stoplight rule. Anyone who claims to have mastered a rule will be judged by the community to have done so if his particular responses agree with those of the community in enough cases. Those who deviate are corrected. One who is incorrigibly deviant with respect to enough rules cannot participate in community life. ${ }^{61}$ There is certainly nothing remarkable about this solution to the skeptical paradox in the context of legal rules; community agreement about at least some applications of legal rules is, at bottom, the explanation for how they can be consistently applied.

However, if it is only the brute fact of community agreement that allows the rules to be determinate, the rule-skeptic can argue that there is no underlying justification for applying the rules the way we do. If we all just agreed to apply them differently, perhaps we could. With this argument in mind, hard cases in which some important political controversy is at stake seem rather troubling: the rule of law appears to be nothing more than the brute force of agreement. The critical rule-skeptic could argue that this deprives the legal system of "something" necessary for its legitimacy.

Perhaps. But the important question is what could possibly be missing? The rule-skeptic might, for example, ask for a justification for the community's agreement about the meaning of the redlight rule each time it is applied. This is, of course, not the same as asking that the rule be justified as a matter of principle or policy. There might be good reasons to use blue lights instead of red ones or to do away with traffic laws altogether. But once we agree to adopt particular rules, and however often we decide to change those rules, there is no corresponding point to asking us to justify our consensus as to what they mean. What would we do if we weren't satisfied with the answer? And on what grounds could we be dissatisfied?

In contrast, the possibility of various outcomes that exists in hard cases does have implications for action. It is not possible to predict with practical certainty how a hard case will be decided. One cannot plan actions as easily when important consequences depend on the resolution of a hard case as when the same consequences depend on the resolution of an easy case. Moreover, hard

${ }^{60}$ See Kripke, Wittgenstein On Rules at 91-92 (cited in note 52).

61 This paraphrases Kripke, whose discussion resonates rather clearly with the discourse of rule application in law. See id. 
cases may require adjudicators and lawyers to consider policy and purposes that can be ignored in easy cases.

But the practical underdeterminacy of hard cases is a far cry from the skeptical possibility that a community could radically change its linguistic practice. That skeptical possibility lacks practical bite, and so will not serve the purpose to which it is put by critical scholars.

2. The deconstructionist defense. Another external line of defense for the strong indeterminacy thesis invokes the deconstructionist techniques of the French post-structuralist Jacques Derrida. ${ }^{62}$ As appropriated by literary critics, deconstruction is a technique that permits new readings of familiar texts. ${ }^{63}$ As practiced by Derrida himself, deconstruction represents an assault on the whole western philosophical tradition. ${ }^{64}$ Like the relationship of the rule-skeptic's defense to Wittgenstein's paradox, the "deconstruction" practiced by critical legal scholars may bear little more than a family resemblance to "deconstruction" as practiced by Derrida.

The deconstructionist version of the indeterminacy thesis makes the ambitious claim that the indeterminacy of legal rules is a function of deep contradictions within liberal society, or of the failure of liberal society to reconcile or mediate a deep contradiction within the collective and individual human self. ${ }^{65} \mathrm{~A}$ concise summary is provided by Gary Peller:

The irrationalist [critical legal scholar] finds legal rules too marginal in their effects and too indeterminate and incoherent in their content to be instrumentally necessary for any particular social formation. Doctrine embodies contradictory ideals of freedom for the self and security from the other so that any right to be free from social regulation violates a right to be free from social harm. Nothing in the content of the rules dictates which side of the liberal contradiction between commu-

62 See, e.g., J.M. Balkin, Deconstructive Practice and Legal Theory, 96 Yale L. J. 743 (1987); Dalton, 94 Yale L. J. at 1007-09 (cited in note 7); Note, Subjects of Bargaining Under the NLRA and the Limits of Liberal Political Imagination, 97 Harv. L. Rev. 475, 476 n.10 (1983). A useful introduction to Derrida is Christopher Norris, Deconstruction (1982). Gary Peller argues that there was a deconstructionist strand in early legal realism. Peller, 73 Cal. L. Rev. at 1222-24 (cited in note 6).

6s See Norris, Deconstruction at 90-125 (cited in note 62).

4 See Irene E. Harvey, Derrida and the Economy of Differance (1986).

65 For a brief overview, see Robert W. Gordon, Critical Legal Histories, 36 Stan. L. Rev. 57, 114-16 (1984). See also Feinman, 30 U.C.L.A. L. Rev. 829 (cited in note 15); Dalton, 94 Yale L. J. at 1667 (cited in note 7). 
nity and autonomy will prevail in any particular instance. ${ }^{66}$

Jay Feinman makes the same sort of argument with respect to contract law:

[M]odern contract law embodies both elements of . . . contradictory notions about the nature of life in liberal society. People are isolates, but they are also members of communities. People desire freedom from others but can only realize freedom through connection with others. In law, the state protects the individual from interference by others, but the state is itself a threat to the individual's autonomy. ${ }^{67}$

The essence of this notion is that the indeterminacy of the law is the inevitable result of fundamental oppositions within the self or within the liberal state, a projection of the collective self.

This view of indeterminacy avoids some of the difficulties of rule-skepticism; for example, it does not rest on a confusion between practical and skeptical possibility. But there are serious problems with the critical charge that, because there are "two deeply antagonistic ideologies at war within the law," no coherent justification of principle can be offered for existing doctrine. For example, Ronald Dworkin has argued that critical scholars have failed to clearly distinguish between "competition and contradiction in principles." trine might be that it reflects a compromise between competing principles, without creating a fundamental contradiction within the doctrine.

More fundamentally, the deconstructionist defense of strong indeterminacy falters because it does not provide any real answer to the argument from easy cases. Let us concede, for the moment, that some legal doctrines embody a tension between community and autonomy resulting in indeterminacy. No matter how many such examples can be proffered, they do not prove that all, or even most, of the law is indeterminate; they do not offer a rejoinder to the argument from easy cases. The legal deconstructionist would have to take all cases, including the easiest ones offered in this essay, and demonstrate both that they are indeterminate and that this indeterminacy is a function of some deep conflict between self

*s Gary Peller, Debates About Theory Within Critical Legal Studies, 1 Lizard 3-4 (1984). This passage is quoted in Boyle, $133 \mathrm{U}$. Pa. L. Rev. at 725-26 \& n.130 (cited in note 6).

${ }^{67}$ Feinman, 30 U.C.L.A. L. Rev. at 847 (cited in note 15).

${ }^{68}$ Dworkin, Law's Empire at 272, 274-75 (cited in note 16). 
and other. Neither demonstration has been made. Instead, the deconstructionist defense simply provides another coherent explanation of why some legal rules are underdetermined over the set of all cases.

The defender of the thesis might argue that the apparent determinacy of easy cases is not a function of the legal rules, but is instead a function of shared values and understandings that determine the result without the aid of legal doctrine. This explanation, however, is inconsistent with the deconstructionist version of the thesis. Clare Dalton recognizes the dilemma:

My analysis, which supports the idea that judicial decisionmaking is indeterminate, is rendered vulnerable by our experience of being able to speculate successfully about how at least some cases will come out. One response is that our ability to speculate has less to do with the determinacy of doctrine than with our sensitivity to cultural values and understandings as they impinge on and are created by our decisionmakers. This implies that while "doctrine-as-rule-system" is indeterminate, "doctrine-in-application" is after all determinate, needing just that infusion of (determinate) cultural value and understanding to make it so. But if doctrinal indeterminacy is produced, as I have suggested, by the same dualities that structure the rest of our life and thought, that affect the very development of our cultural values and understandings, then indeterminacy must exist at all these levels. Our seeming ability nonetheless to understand and to predict (in a historically contingent fashion) the particular links that decisionmakers create between particular arguments, and the particular fact situations decisionmakers construct from the testimony submitted to them, requires us to search for other explanations.

Dalton offers only poetry in a footnote as explanation. ${ }^{69}$ The data-that is, our ability to predict legal decisions-contradict the hypothesis that fundamental dualities make all such predictions impossible. Nevertheless, it is possible to postulate that there is some hidden explanation that only awaits discovery to clear up the seeming inconsistency. But a belief that is made unshakeable in this way is dogma - "irrefutable and beyond the reach of attack."70 The deconstructionist defender of strong indeterminacy has

"Dalton, 94 Yale L. J. at 1009-10, 1010 n.24 (cited in note 7) (original emphasis).

30 Wittgenstein, Culture and Value at $28 \mathrm{e}$ (cited in note 1 ). 
yet another rejoinder: I am employing the very "logocentric" standards that are at issue-that is, $I$ am also resorting to dogma. In a sense, no reply can be given to the argument that there can be no arguments. I will, however, offer two observations. The first is that critical legal scholarship has not abandoned logocentric standards: the critical scholars do not make the punning, irrationalist arguments characteristic of Derrida. ${ }^{71} \mathrm{My}$ second observation is that the legal deconstructionist's attempt to argue against rationality is self-defeating. The act of arguing assumes the standards of rationality that the deconstructionist attempts to call into question. ${ }^{72}$

\section{Epiphenomenalism}

I will examine one final defense of the strong indeterminacy thesis against the argument from easy cases. The epiphenomenalist defense grants the existence of easy cases but denies that the law explains these results, on the ground that legal doctrines, constitutions, statutes, case law, and the like are mere epiphenomena-things without any real causal role in the results. ${ }^{73}$ The legal epiphenomenalist argues that although legal doctrine is chronologically prior to the result in a particular case, and although variation in doctrine may appear to explain variation in result (at least within the limited domain of easy cases), the doctrine does not determine the result because in fact both doctrine and result are determined by something else.

This is the line of argument that Dalton considered and rejected in the passage quoted above. ${ }^{74}$ Joseph Singer, however, seems to adopt this line of defense against the argument from easy cases:

${ }^{31}$ For an example of Derrida's use of punning arguments, homonym, and metaphor, see Jacques Derrida, Plato's Pharmacy, in Dissemination 61 (Barbara Johnson trans. 1981). Donald Brosnan has compared Derrida's style of argument with that employed in critical scholarship. See Donald F. Brosnan, Serious But Not Critical, 60 So. Cal. L. Rev. 259, 36088 (1987).

${ }^{72}$ My claim is that this particular deconstructionist argument is self-defeating in the sense that John Finnis calls "operational self-refutation." The act of arguing against rationality is not logically incoherent; rather, it is performatively inconsistent in that the very act of making such an argument is inconsistent with the proposition asserted. John Finnis, Natural Law and Natural Rights 74 (1980).

$7 s$ Elster explains that "the problem of epiphenomena . . . refers to a correlation between two variables that does not stem from a causal relation between them, but from their common relation to some third variable." Jon Elster, Explaining Technical Change 47 (1983). See also David Lewis, Causation, in Ernest Sosa, ed., Causation and Conditionals 180,190 (1975).

34 See note 69 and accompanying text. 
The indeterminacy of arguments is logically distinct from the arbitrariness of choices. It is perfectly possible for there to be predictable patterns of behavior and decisionmaking even though the arguments advanced to justify the choices do not determine the outcomes. Saying that decisionmaking is both indeterminate and nonarbitrary simply means that we can explain judicial decisions only by reference to criteria outside the scope of the judge's formal justifications. . . .

Decisions that are not determined by a coherent theory ... may be predictable if we know enough about the context in which the decision is made. This context includes the institutional setting (for example, court or legislature), the customs of the community (such as standard business practices), the role of the decisionmaker (judge, legislator, bureaucrat, professor), and the ideology of the decision maker. ${ }^{75}$

Singer adds that,

Legal doctrines are always potentially indeterminate. Judges can move the line between rules and exceptions, or create new exceptions. They can nullify the application of a rule to a particular case by widening a legally enforceable standard so far that it eclipses the apparently applicable rule. ${ }^{76}$

It is important to note that the epiphenomenalist defense against the argument from easy cases requires that the link from the real, underlying causal factors to the results in particular cases does not go through the legal doctrines. If the causal chain went through the intentional actions of judges who decided cases on the basis of doctrine, then the indeterminacy thesis would be false: doctrines would determine results, although the doctrines would in turn be determined by something else.

The question then becomes precisely how the causal linkage works. The advocate of the view that doctrines do play a causal role, even though that role is usually underdeterminative, has a simple and natural explanation for how doctrines influence outcomes: when judges take up the internal perspective-that is, when they consider the limits legal doctrine places on possible re-

78 Singer, 94 Yale L. J. at 20-21 (cited in note 6) (original emphasis). Kairys makes a similar claim: "[I]t is only the social context in a particular situation that makes one outcome more likely than another. A legal-sounding rationale can be made for almost every result." Kairys, 52 Geo. Wash. L. Rev. at 247 (cited in note 7) (original emphasis).

${ }^{76}$ Singer, 94 Yale L. J. at 22 (cited in note 6). 
sults-they act intentionally ${ }^{77}$ in choosing results within the legal limits they perceive. Given the existence of an alternative hypothesis that includes a specific account of the mechanism by which doctrine determines results, the burden is on the legal epiphenomenalist to provide an equally plausible account. Can the epiphenomenalist defenders of strong indeterminacy offer a similarly adequate causal explanation-that is, can they suggest the microfoundations of indeterminacy? ${ }^{78}$

The primary hurdle facing any such epiphenomenalist account of why some cases appear to be easy is "saving the appearances": the account must explain the many reports by legal actors that legal rules do constain their decisions. A brief analysis of the explanations offered by critical legal scholars for the ideological character of legal discourse reveals the problems a legal epiphenomenalist faces when trying to construct a causal mechanism independent of the law. Critical scholars usually reject historical materialist explanations that begin with the premise that legal discourse, as part of the social superstructure, can be explained in terms of the economic base. For example, most critical scholars reject the crude Marxist view that the law has the content that it does in order to best serve the interests of the capitalist class. ${ }^{79}$ Nor have critical scholars been tempted by the more sophisticated, but still functionalist, premise that the legal system is relatively autonomous because that autonomy is in the interest of the capitalist class. ${ }^{80}$

Rather, most critical scholarship takes a more complex view of the way the legal superstructure interacts with social, political, and economic institutions. Duncan Kennedy writes,

[L]aw cannot usefully be understood, by someone who has to deal with it in all its complexity, as "superstructural." Legal rules the state enforces and legal concepts that permeate all aspects of social thought constitute capitalism as well as responding to the interests that operate within it. Law is an aspect of the social totality, not just the tail of the dog. The

77 For the purpose of simplicity in this argument, I do not distinguish intentional from causal explanation. For an analysis of the difference, see Elster, Explaining Technical Change at 17, 19-20 (cited in note 73).

${ }^{78}$ See Elster, Making Sense of Marx at 5-8 (cited in note 26).

79 This view is "class instrumentalism." See Collins, Marxism and the Law at 27-34 (cited in note 36). Jon Elster argues that until 1850 Marx held a similar theory-that the state was a mere instrument for the economically dominant classes. Elster, Making Sense of Marx at 408 (cited in note 26).

so Elster, Making Sense of Marx at 408 (cited in note 26); Collins, Marxism and the Law at 47.52 (cited in note 36 ). 
rules in force are a factor in the power or impotence of all social actors (though they certainly do not determine outcomes in the way liberal legalists sometimes suggest they do). Because it is part of the equation of power rather than simply a function of it, people struggle for power through law, constrained by their limited understanding and limited ability to predict the consequences of their maneuvers. To understand law is to understand this struggle as an aspect of class struggle and as an aspect of the human struggle to grasp the conditions of social justice. ${ }^{81}$

This broad view of social hegemony posits a closed system of interaction among legal doctrines, social values, and economic base, so that no mechanism external to it influences results in legal cases in any determinate way. This closed system-of which legal doctrine is an integral part-is extremely successful in determining the results in particular cases. In this respect, the critical perspective is incompatible with any attempt to reduce legal doctrine to mere epiphenomena.

Accordingly, it is not surprising that critical scholars' attempts to defend the strong indeterminacy thesis by offering an explanation of how results are determined by "underlying forces"-and not, in any way, by legal doctrine-are notoriously weak. Thus when Singer postulates that an explanation could be offered in terms of "the context"-including "institutional setting," "customs of the community," "role of the decisionmaker," and "the ideology of the decisionmaker"-he provides no concrete account of the mechanism by which these factors determine the result. Moreover, he offers no argument why such factors do not mold the legal doctrines and those doctrines, in turn, dictate the results in particular cases.

If critical scholarship were to offer microfoundations for the epiphenomenalist defense of indeterminacy, the explanations would have to account for the intentional nature of judges' legal decision making. Three sorts of explanations could be offered. One would be an intentional explanation: judges pay no attention at all

* Duncan Kennedy, Legal Education as Training for Hierarchy, in Kairys, ed., The Politics of Law 40, 49-50 (cited in note 2) (original emphasis). See also Gabel and Harris, 11 N.Y.U. Rev. L. \& Soc. Change at 369 n.1 (cited in note 30) (orthodox Marxist view is instrumentalist and false because it misunderstands the role of legal ideas in the maintenance of social hierarchies); Boyle, 133 U. Pa. L. Rev. at 722-25 (cited in note 6); Robert W. Gordon, New Developments in Legal Theory, in Kairys, ed., The Politics of Law 281, 285-92 (cited in note 2). 
to the rules, decide the case on the basis of their ideology, and then dress up the results with doctrinal justifications. The problem with an intentional explanation is that it falls short of being a claim of universal application; judges surely sometimes pay some attention to the rules and surely sometimes feel that their decisions are constrained by the rules, especially in cases where they have no emotional or political stake in the outcome.

The second sort of explanation would be subintentional. ${ }^{82}$ The epiphenomenalist defender of strong indeterminacy could give an account of a psychological mechanism that causes judges to believe that they are deciding, at least in part, on the basis of the rules, when actually other factors account for the decision. Much of the talk in critical scholarship about "ideology" or "structures of thought" suggests such a subintentionalist explanation. ${ }^{83}$ Unfortunately, these ideas are woefully underdeveloped in the critical literature.

The third sort of explanation would be supraintentional: it would demonstrate that the predictability of legal outcomes is an unintended consequence of interaction between individual decisions, and that legal outcomes, although they correlate with the rules, are not part of a causal chain that goes through the rules..$^{84}$ To my knowledge, critical scholars have never attempted such an explanation. In sum, while sub- and supraintentional explanations of judicial decision making are worth pursuing, the underdeveloped version of the epiphenomenalist defense of the strong indeterminacy thesis that has been presented by critical scholars fails to rebut the argument from easy cases.

\section{Weak Versions OF the InDETERminacy Thesis}

Perhaps because the strong version of the thesis seems indefensible, a number of critical legal scholars have abandoned it. In its stead, various modified or "weak" versions of the indeterminacy thesis have been proposed. I will consider these versions under two general headings.

\section{A. The Important-Case Indeterminacy Thesis}

According to the first weak version, indeterminacy is said to

${ }^{82}$ See Elster, Explaining Technical Change at 17 (cited in note 73).

s3 See, e.g., Frances E. Olsen, The Family and the Market: A Study of Ideology and Legal Reform, 96 Harv. L. Rev. 1497, 1567 (1983).

84 Elster, Explaining Technical Change at 17 (cited in note 73). 
hold, not for the set of all cases, but for some subset of cases. In particular, some critical scholars advance the limited, but still ambitious, claim that all interesting or important cases are indeterminate. This "important-case" version of the thesis might retain almost all the power of the strong thesis: if it were true, the only easy cases would turn out to be uninteresting or unimportant ones. The argument from easy cases would be true but insignificant-of no practical importance.

The viability of the important-case indeterminacy thesis depends critically on the criteria that define the subset of "important" cases. Unless importance is defined by criteria other than practical indeterminacy ${ }^{85}$ itself, the thesis will be trivial: indeterminate cases are indeterminate. This tautology does not undercut the argument from easy cases.

I have seen no critical scholarship that provides adequate criteria for the important-cases version of the thesis. For example, David Kairys concludes, "Our legal norms are broadly and vaguely stated. They do not logically lead to particular results or rationales concerning most important or difficult issues." ${ }^{86} \mathrm{He}$ continues in a footnote, "There are, of course, cases and areas of the law where there is considerable clarity and predictability." Thus, Kairys restricts the scope of the thesis to "important or difficult" cases. The tautology in Kairys' second class is clear: "difficulty" is the criteria for indeterminacy, but difficult cases are difficult because the law does not give a determinate result. Alternatively, Kairys' first class includes "important" cases. Unfortunately, he does not tell us what he means by importance. If by important cases, he means cases whose outcomes will significantly effect people's lives, then surely the thesis is false. Kairys admits that significant aspects of the laws that govern economic transactions are determinate, and surely this branch of law has significant implications for our lives. On the other hand, if by "important" cases, Kairys means those cases that present a question of first impression, then his view of the indeterminacy thesis once again becomes a mere tautology: important cases are important because the law does not give a determinate result.

Mark Tushnet has suggested a more refined approach. In the context of a critique of existing constitutional theories, Tushnet argues against the proposition that the constraints of legal craft

s By "practical indeterminacy" I mean cases that are "hard" in one of the senses discussed above in the text accompanying note 38 .

${ }^{38}$ Kairys, Legal Reasoning at 13, 17 n.6, 17 n.6 (cited in note 5). 
could rescue Herbert Wechsler's justification of constitutional law as a body of neutral principles. ${ }^{87}$ Tushnet argues that prior decisions cannot constrain present decisions because "it turns out that the limits of craft are so broad that in any interesting case any reasonably skilled lawyer can reach whatever result he or she wants," but in a footnote, we find an explicit recognition that the critical bite of the indeterminacy thesis may depend on the restriction of its domain of application:

The significance of this claim, of course, turns on the definition of "interesting." It seems certain that all cases decided by the Supreme Court would fit any reasonable definition. Given constitutional theory's focus on the role of the Supreme Court, that certainly might be enough. I suggest, however, that the claim holds even if an "interesting" case is defined as one that some lawyer finds worthwhile to pursue. If this suggestion is correct, the craft interpretation cannot constrain courts at all. ${ }^{88}$

Even Tushnet's statement of the important-case version of the indeterminacy thesis is circular. The Supreme Court certainly uses indeterminacy or underdeterminacy of practical importance as criteria for selecting the cases it hears. On most occasions where the rules laid down lead to determinate results, the Court simply denies review. In those cases in which the Court feels sufficiently strongly that the result below is plainly wrong, it reverses by summary procedure. The Supreme Court may well be constrained by prior decisions without deciding to make easy cases a major part of its caseload. Thus, the Court's criteria for review undercut Tushnet's attempt to escape a tautological definition of "importance" by using Supreme Court cases to define the "important" cases for which indeterminacy holds.

Likewise, Tushnet's second proposed restriction on the domain of application does not succeed in producing a viable version of the important-case indeterminacy thesis. To begin with, it is reasonable to assume that indeterminacy is itself a criterion used by lawyers to decide which cases are worthwhile to pursue; some cases are pursued because they are "interesting" (or profitable) in the sense that the result is indeterminate. It is also clear, however, that lawyers pursue particular cases where the law produces practi-

${ }^{87}$ Herbert Wechsler, Toward Neutral Principles of Constitutional Law, 73 Harv. L. Rev. 1 (1959).

${ }^{88}$ Tushnet, 96 Harv. L. Rev. at 819, 819 n.119 (cited in note 8). 
cally determinate results. For example, plaintiffs' lawyers frequently initiate legal actions that they are certain to win. Defense lawyers, however, may resist even in such determinate cases for strategic reasons of delay. Tushnet's suggestion that any case a lawyer finds worthwhile to pursue is indeterminate is easily refuted by the existence of easy cases that are in fact pursued.

I do not mean to claim that there is not a substantial set of cases that are indeterminate. Nor do I mean to suggest that the existence of this set has no critical implications. It may well have critical implications, which I discuss in the final part of this essay. Also, I cannot offer a proof that no adequate subset of cases could ever be defined such that the criteria for inclusion would not render the important-case indeterminacy thesis tautological. However, I do claim that critical scholarship has failed to come forward with such criteria, and thus has failed to establish the thesis that all the "interesting" or "important" cases are indeterminate in a way that is not a mere tautology. Without telling us if and when indeterminacy is really important, critical scholars cannot show that even this restricted form of the thesis has bite.

\section{B. The Modally Weakened Indeterminacy Thesis}

One can also weaken the modal status of the indeterminacy thesis in order to avoid the argument from easy cases. ${ }^{89}$ For example, Robert Gordon suggests that,

[The argument from easy cases] rests ... on a misunderstanding of what the Critics mean by indeterminacy. They don't mean-although sometimes they sound as if they do-that there are never any predictable causal relations between legal forms and anything else. . . . The Critical claim of indeterminacy is simply that none of these regularities are necessary consequences of the adoption of a given regime of rules. The rule-system could also have generated a different set of stabilizing conventions leading to exactly the opposite results and may, upon a shift in the direction of political winds, switch to those opposing conventions at any time. ${ }^{90}$

This passage has been cited by both Joseph Singer and Charles Yablon as providing the correct explanation of the indeterminacy

\footnotetext{
s" Properly speaking, "modal status" refers only to logical possibility, contingency, or necessity. Here, I am using it in a broader sense-to refer to logical, physical, social, and actual possibilities.

90 Gordon, 36 Stan. L. Rev. at 125 (cited in note 65) (original emphasis).
} 
thesis and Duncan Kennedy has recently taken a similar position. ${ }^{91}$ Singer and Yablon argue that the indeterminacy thesis can be squared with the existence of easy cases by modifying it to claim only that legal rules do not necessarily produce determinate results in particular cases, thus weakening the modal status of the thesis.

The significance of the modally weakened indeterminacy thesis hangs on the meaning given to "necessity," and the meaning given to "necessity" depends, in turn, on the sorts of possibilities that are allowed to demonstrate that case results need not follow from particular legal rules. Neither Gordon nor Singer makes this issue explicit. To understand their position, it will help to explore various interpretations of necessity and possibility by using the philosophical concept of "possible worlds." that a proposition is necessarily true if it is true in all possible worlds. What we mean by "necessity" varies as we admit of more or fewer possible worlds. My discussion here distinguishes among four sorts of possible worlds: (1) logically possible worlds-those that are not internally inconsistent; (2) physically possible worlds-those that are not inconsistent with the laws of science; (3) socially possible worlds-those that do not violate our understanding of the limitations on the behavior of humans and their communities; ${ }^{93}$ and (4) practically possible worlds-those that are within the realm of sufficient likelihood to be of practical consequence. ${ }^{94}$

There are at least two interpretations of "necessity" in the modally weakened indeterminacy thesis. First, "necessity" might be seen as a requirement that the application of particular legal

91 Singer, 94 Yale L. J. at 20 n.55 (cited in note 6); Yablon, 6 Cardozo L. Rev. at 924 n.22 (cited in note 40); Kennedy, Critical Phenomenology at 166 (cited in note 4) ("Rule application is something that does happen, but it is never something that has to happen.").

${ }_{92}$ For my purposes here, "variation in context" would suffice as well as would "possible worlds." My classification scheme is loosely based on the philosophical work of David Lewis, who uses the term "accessibility" to categorize the possible worlds. Thus my category of "physically possible worlds" corresponds to Lewis's "nomologically accessible" worlds. See David Lewis, On the Plurality of Worlds 20 (1986).

${ }^{93} \mathrm{By}$ distinguishing between physically and socially possible worlds, I mean to avoid taking a stand on whether social limits on human action can be reduced to the consequences of physical laws. Those who are convinced that such a reduction is not only possible, but necessary, should disregard my third category.

s4 By this I mean possible future states of the actual world. Thus, such practically possible worlds must be "historically accessible"-that is, they must share the history of our world up until the present. See Lewis, On the Plurality of Worlds at 8 (cited in note 92). In addition, I mean "practical possibility" to convey the sense that the possibility in question has consequences for human action. 
rules in particular cases produce identical results in all logically, physically, or socially possible worlds. Stated this way, the modally weakened thesis may be true, but it lacks critical bite. In every application of a legal rule to a particular case, we can imagine a possible world in which the outcome would be different than it is in our world. But in order for this version of the modally weakened thesis to be true as applied to at least some easy cases, the sense in which legal rules are indeterminate must become trivial. For example, we could imagine a world so different that this essay violates the securities laws, but this possibility is trivial; it has no claim on our attention.

I have already discussed examples of this first sort of modal weakening. Recall Gary Peller's treatment of the constitutional requirement that the president be at least thirty-five years of age:

[E]ven a seemingly determinate clause such as the minimum age for presidents remains indeterminate. It is possible the age thirty-five signified to the Framers a certain level of maturity rather than some intrinsically significant number of years. If so, it is open to argument whether the translation in our social universe of the clause still means thirty-five years of age. It may be that a younger age should be used since children today, through mass media, are more worldly at an earlier age..$^{85}$

Thus, Peller argues that it is possible that the signifier "thirtyfive" could have stood for the same concept for which we use the signifier "of responsible age." Of course, this is logically, physically, and socially possible. In those worlds, the age requirement is not necessarily determined. In practically possible worlds, however, it is. Assuming judges use the drafters' language to divine their intent, Peller's world is not "historically accessible": absent startling discoveries about eighteenth-century linguistic practice, the drafters cannot be thought to have taken " 35 years of age" to embrace Peller's flexible "maturity" concept. ${ }^{98}$ As long as "not necessarily determined" refers only to this sort of nonpractical possibility,

ss Peller, 73 Cal. L. Rev. at 1174 (cited in note 6) (emphasis added).

96 Alternatively, the critic could argue that even if the drafter's intentions are clear, judges could simply choose to abandon it and adopt Peller's "maturity principle" for, say, reasons of policy. This argument, however, ignores the law's internal standards-that judges square their decisions with legal doctrine and not just do what they think would be good policy-and in doing so, begs the question of whether there is something in the language of the age requirement that would allow it to be read as Peller suggests it can. Saying it might be good policy is something else. 
Gordon's reformulation of the indeterminacy thesis has no practical consequence.

But a second interpretation of "necessity" may rescue the modally weakened indeterminacy thesis. Gordon seems to recognize that the sense in which the relationship between legal rules and particular cases is "necessary" must be formulated so as to retain its critical bite. Thus, he suggests that "a shift in the direction of political winds" might alter the outcome of the application of a legal rule to any particular case. This version of the thesis may have some critical bite. The fact that the legal system responds to political pressure is an obvious cause of underdeterminacy, or even indeterminacy, in the law as applied in particular cases. But how much bite there is in Gordon's version of indeterminacy depends on how may cases realistically will be affected by it. It is not difficult to imagine easy cases that would be unaffected by any change in our world fairly described as "a shift in the political winds." Politics may enlarge judicial discretion, but Gordon must go further in his definition of "necessity" and "shift in the political winds" before his version of the modally weakened indeterminacy thesis can demonstrate that most law is indeterminate in all practically possible worlds.

What then is the truth about indeterminacy? There is certainly room for dispute, but as practical boundaries for the debate, three conclusions are firm. First, legal doctrine underdetermines the results in many, but not all, actual cases. That is to say that aside from the easiest cases, aspects of the outcome are rule-guided but not rule-bound. For example, in the most routine cases, the amount of a traffic fine or of a damage award may vary within some range. Second, although there may be some cases in which the result is radically underdeterminate, in the sense that any party could "win" under some valid interpretation of legal doctrine, it does not follow that the doctrine itself is indeterminate over all cases. For example, the three-pronged test for impermissible state establishment of religion, articulated in Lemon v. Kurtz$m a n,{ }^{97}$ is often criticized as highly underdeterminate. But, in spite of any uncertainty about some applications of the Lemon test, we can be quite sure that a court applying the Lemon test would strike down any law giving parochial school teachers a pay raise out of state funds. ${ }^{98}$ Third, it is pure nonsense to say that legal doctrine is completely indeterminate even with respect to very

97403 U.S. 602, 612-13 (1971).

${ }^{23}$ These are, of course, the facts of the Lemon case itself. 403 U.S. at 606-07. 
hard cases. Even in the hardest hard case, legal doctrine limits the court's options. One of the parties will receive a judgment, not some unexpected stranger; the relief will be related to the dispute at hand and will not be a declaration that Mickey Mouse is the President of the United States.

Inside these boundaries, there are some who will contend that most of the business of the courts is so rule-guided that the law exhibits "practical determinacy"-that is, for all practical purposes, results are determined by the existing doctrines. Others will contend that most of the business of the courts is so underdetermined that the law is, for practical purposes, indeterminate. This dispute is partly empirical and partly conceptual. The empirical dispute over how much flexibility exists in the application of legal doctrine could be resolved by careful study of the cases themselves, but the extent to which flexibility counts as "practical determinacy" or "practical indeterminacy" raises a dispute over these concepts. We can also dispute what should count as a "case." Some might argue, for example, that a claim that the first paragraph of this essay slanders Gore Vidal does not even rise to the level of a "case." But making this argument illustrates my point: the reason that easiest cases are not "cases" at all is that the law's relative determinacy does not permit us to make a "case" out of them. The very determinacy of the law prevents us from even recognizing them as cases in any grand empirical study to determine the percentages of hard and easy cases.

My point is that whatever counts as a case, whatever counts as practical determinacy, and whatever empirical study reveals, the truth about indeterminacy is different from that implied by most, if not all, formulations of the indeterminacy thesis in critical legal scholarship. These versions of indeterminacy will seldom, if ever, make a practical difference to the parties to a dispute. It is for this reason that $I$ conclude that these current critical versions of the indeterminacy thesis are dogma.

\section{The Critical Preoccupation With Indeterminacy}

At this point, an explanation is in order. How is it that strong versions of the indeterminacy thesis play so large a role in critical legal scholarship, if they are simply dogma? As a matter of intellectual history, I believe that critical scholarship's preoccupation with the indeterminacy thesis can be traced to the movement's 
roots in legal realism. ${ }^{99}$ Realists such as Jerome Frank, Joseph Bingham, and Karl Llewellyn were deeply skeptical of the role of legal rules as determinants of actual legal decisions. ${ }^{100}$ Critical scholars seem to have inherited this skepticism. ${ }^{101}$

The realists' rule-skepticism was attributable to their reaction to the legal formalists' thesis that outcomes in particular cases could always be arrived at, by a deductive method, from the existing body of law. ${ }^{102}$ It was not difficult for the realists to demonstrate as an empirical matter that legal formalism was false; the existence of even a single instance of underdetermination refuted legal formalism. The indeterminacy thesis has its historical roots in this realist refutation of formalism. One might say that much of critical legal scholarship has generalized this refutation; it takes the realists' examples of underdetermination not only as the paradigm cases of legal rule application, but as the only sort of rule application that is possible.

A second factor also accounts for the critical obsession with the indeterminacy thesis: the emphasis on case method instruction in legal education. Critical scholarship is a product of American law schools; most critical scholars have been educated in legal institutions that teach the law through the study of appellate decisions. The vast majority of critical scholarship is produced by persons now teaching in those same institutions. Many of these scholars went straight from attending a law school to teaching at one-possibly with a brief stint as a clerk for a federal appellate judge. ${ }^{103}$

Appellate decisions, however, are a rather skewed sample of the possible applications of legal rules to particular disputes. In the vast majority of possible rule applications, no one even bothers to consider legal action because no one has been disturbed enough

80 For a short introduction to the realist critique of legal formalism, see Edward A. Purcell, Jr., The Crisis of Democratic Theory chs. 5 \& 9 (1973).

${ }^{100}$ See Jerome Frank, Law and the Modern Mind 27-31 (1930); Joseph Walter Bingham, My Philosophy of Law, in My Philosophy of Law: Credos of Sixteen American Scholars 5 (1941); Karl N. Llewellyn, A Realistic Jurisprudence-The Next Step, 30 Colum. L. Rev. 431 (1930).

${ }^{101}$ This intellectual heritage is acknowledged in a number of critical pieces. See, e.g., Kennedy, 89 Harv. L. Rev. at 1700 (cited in note 4); Singer, 94 Yale L. J. at 48 (cited in note 6) ("The strand of contemporary Critical Legal Studies that focuses on demonstrating the contradictions and indeterminacy in legal theory is an extension of . . . legal realism.").

${ }^{102}$ See John M. Zane, German Legal Philosophy, 16 Mich. L. Rev. 287, 338 (1918)

("Every judicial act resulting in a judgment consists of a pure deduction.").

${ }^{109}$ For similar points, see Louis Menand, Radicalism for Yuppies, New Republic 20 (Mar. 17, 1986). 
to undergo the trouble and expense of legal redress. In a large number of other potential cases, the police or a lawyer will explain that no legal rule even arguably permits the law to correct the perceived wrong. Of those potential cases that do arguably permit legal redress, a great number will be settled either by an apology, a monetary settlement, an agreement to dismiss the action for lack of proof, a stern warning from the police, or a guilty plea. Of the few cases that go to trial, a vast majority will not be appealed. Most of those that are appealed will be disposed of without a published decision. And only a tiny percentage of the published decisions are of sufficient interest to warrant inclusion in a casebook for the teaching of law students. And a significant number of these cases are Supreme Court cases. This is important because a large share of decisions at the trial or intermediate level will be strongly determined by past law. Lower courts handle a steady diet of "easy" cases; and they are not free to change or evade existing doctrine. It is only the Supreme Court that has this freedom; a focus on Supreme Court decisions thus can easily skew one's perspective.

Furthermore, one of the primary criteria for inclusion in a casebook may be indeterminacy itself: practically indeterminate cases may be useful pedagogically because they can be used to illustrate both the methods and limits of formal legal reasoning as well as the role of principle and policy. The generalization that the law is practically indeterminate may thus stem from the predominance of such examples in the materials with which legal scholars work on a daily basis. ${ }^{104}$

Finally, critical legal scholars have a strong practical motive for belief in the indeterminacy thesis. If one believes that the rules are strongly determinate, but fundamentally wrong, one is left with very little room to maneuver within the limited horizons of legal scholarship. The notion that it is possible to achieve radical results working with the existing body of legal doctrine-because the seeming constraints are illusory-has powerful attraction for those committed to social change, but whose professional lives are confined to the academy and not the capitol buildings.

104 For a candid admission of selection bias at work in critical scholarship, see Dalton, 94 Yale L. J. at 1003-04 (cited in note 7) (most source material for article on contract law from a single casebook), and Feinman, $97 \mathrm{Harv}$. L. Rev. at 679 (cited in note 7) (source material for article on promissory estoppel doctrine in contract law limited mainly to appellate cases). 


\section{INDETERMINACY AND MYSTIFICATION}

But this appeal is superficial. Far from enabling a progressive transformation of legal practice, the indeterminacy thesis, at least the strong version, disempowers the critique of legal ideology that critical scholars hope will facilitate emancipatory social change. Seen in broad terms, their critique has two parts. First, the mystification thesis will unveil the structures of domination masked by legal doctrine. Second, the indeterminacy thesis will explain how domination circumvents the apparent autonomy of the law and frees legal actors from the apparent constraints imposed by the existing rules. Thus, mystification and indeterminacy are the intellectual foundations both for a program of external critique that will reveal the law to the layman for what it is, and for an internal critique through which progressive legal actors will freely use legal practice to achieve emancipatory ends.

My contention is that the strong indeterminacy thesis undercuts, rather than advances, the projects of both internal and external critique. Because the strong indeterminacy thesis calls for disengagement from the form and conventions of discourse that makes legal practice possible, the thesis blunts an internal critique of the law. Stanley Cavell puts the point as follows:

The internal tyranny of convention is that only a slave of it can know how it may be changed for the better, or know why it should be eradicated. Only masters of a game, perfect slaves to that project, are in a position to establish conventions which better serve its essence. This is why deep revolutionary changes can result from attempts to conserve a project, to take it back to its idea, keep it in touch with its history. To demand that the law be fulfilled, every jot and tittle, will destroy the law as it stands, if it has moved too far from its origins. Only a priest could have confronted his set of practices with its origins so deeply as to set the terms of Reformation. ${ }^{105}$

Cavell's idea can be put into a legal context by examining the critical legal theory of Roberto Unger. Unger identifies "deviationalist doctrine" as the positive alternative for legal scholarship. The project of deviationalist doctrine must maintain "the minimal characteristics of doctrine" that is "the willingness to take the ex- 
tant authoritative materials as starting points."108 Like the Reformation, Unger's program acknowledges the structure from which it hopes to deviate. The indeterminacy thesis, however, undercuts the project of deviationalist doctrine at its starting point. If there is a measure of determinacy in the law, and legal discourse and reasoning are more than mere apologies for domination, then Unger's deviationalist doctrine begins with a flawed, but at least functional, language with which to embark on the creation of a more humane legal order. But if the law is indeterminate, and legal reasoning a sham, then they cannot serve as the raw material for constructing a body of doctrine with emancipatory potential-deviationalist doctrine itself would be incapable of effecting real change. Instead, the social order would remain governed by the underlying ideology or political and economic forces-and if the forces were to change, then the doctrine would not need to do so. Under the strong indeterminacy thesis, legal doctrine becomes "a wheel that can be turned though nothing else moves with it," and so it "is not part of the mechanism."

Another argument made in favor of the liberating potential of the indeterminacy thesis is that it frees legal actors from the constraint of legal rules. One interpretation of this concept of liberation closely resembles Sartre's existentialist conception of human freedom: ${ }^{108}$ legal actors must be made to realize that they are radically free to make decisions unconstrained by legal doctrine. Thus Singer argues that acceptance of the indeterminacy thesis will "allow us consciously to assume responsibility for what we do."109 Similarly, the deconstructionist version of the indeterminacy thesis may be liberating in the sense of enabling what Derrida calls "free play." "130 Legal actors realize that they-and everyone else-always have been free to do as they please without bothering to construct interpretations of legal doctrine to justify their actions.

This is not the place for extended consideration of this conception of freedom. I do wish, however, to make an observation

${ }^{108}$ Roberto Mangabeira Unger, The Critical Legal Studies Movement, 96 Harv. L. Rev. 561, 576-83, 577 (1983).

${ }^{207}$ Wittgenstein, Philosophical Investigations If 271 (cited in note 52).

${ }^{108}$ Peter Gabel's early work attempted to incorporate Sartre's thought directly into legal theory. See Peter Gabel, Intention and Structure in Contractual Conditions: Outline of a Method for Critical Legal Theory, 61 Minn. L. Rev. 601 (1977). For a recent description of Sartre's influence on critical scholarship, see Boyle, 133 U. Pa. L. Rev. at 761-62 (cited in note 6).

${ }^{109}$ Singer, 94 Yale L. J. at 52 (cited in note 6).

110 See Jacques Derrida, Of Grammatology xix (Gayatri Chakravorty Spivak trans. 1976) (translator's preface). 
about its implications: the sort of freedom brought about by acceptance of the strong indeterminacy thesis disassociates internal critique from programmatic social change. This radical sort of freedom might enable individual legal adjudicators, practitioners, and scholars to undergo "conversions," liberating them from the constraints of doctrine. But the nature of such a liberation is ambiguous. It is hardly clear that liberating those who wield legal power from the "mistaken" belief that legal doctrine constrains their actions will have a progressive effect. If the mystification thesis is correct, then acceptance of the indeterminacy thesis also will awaken those in power to the fact that legality is no barrier to repression. ${ }^{111}$

Singer recognizes the argument that "if we let judges do just what they want, they would inevitably exercise judicial power in oppressive ways," and responds:

But people do not want just to be beastly to each other. To suppose so is to ignore facts. People want freedom to pursue happiness. But they also want not to harm others or be harmed themselves. The evidence is all around us that people are often caring, supportive, loving, and altruistic, both in their family lives and in their relations with strangers.

It is also not true that, if left to do "just what they like," government officials will necessarily harm us or oppress us. They may do these things if that is what they want to do. But it is simply not the case that all government officials admire Hitler and Stalin and use them as role models. ${ }^{112}$

It is possible that all that stands between us and a progressive system of justice is the elimination of the myth that legal rules constrain judges, but the violent lessons of human history place a heavy burden of persuasion on those who make that claim. Singer's view is profoundly optimistic.

The notion that internal critique will lead to liberation from the illusory bonds of legal doctrine resembles another candidate for the positive program to be advanced by internal critique. Thus, some critical scholars may reject Unger's program of deviationalist doctrine altogether. Unger's project, the transformation of existing legal rights into destabilization rights that would shake up rigid hierarchies, operates on the assumption that adjudication should,

11 This point is similar to criticism of the realists. See Singer, 94 Yale L. J. at $48-49$ (cited in note 6).

${ }^{112}$ Id. at 54, 54-55. 
at least sometimes, be a process of rule application. ${ }^{113}$ Some critical scholars suggest instead that the notion of adjudication as rule application should be replaced with "ad hoc, contextualized judgments." 114 Expressed in traditional terms, the rule of law should be replaced by the anti-rule of pure equity. ${ }^{115} \mathrm{But}$ this proposal faces a difficulty similar to that encountered by the radical notion of freedom: the implications of standardless adjudication for the transformation of society are ambiguous. Moreover, once it is conceded that the law is often practically determinate, the concomitant predictability of many legal outcomes-providing individuals the ability to plan their conduct with some assurance about its legal consequences-surely has some importance. It is difficult even to imagine a modern bureaucratic, industrial society in which all disputes are resolved on the basis of "contextualized, ad hoc judgments." Before we accept the indeterminacy thesis on the basis that it will enable us to move to such a society, we may reasonably expect to know more about where we are going, not just how we might get there.

This discussion leads us to the implications of indeterminacy for the other side of the critical agenda for reform: external critique of the law. Critical scholars often rely on the argument that the indeterminacy thesis delegitimizes the legal process. ${ }^{116}$ To the extent that legal doctrine constitutes a rhetoric that legitimizes relations of domination, the indeterminacy thesis undercuts the effectiveness of the legitimation.

But the indeterminacy thesis also undercuts the mystification thesis. For example, the claim that legal discourse reifies social relationships loses much of its critical bite when considered in tandem with the indeterminacy thesis. James Boyle points out this contradiction: "If the frozen metaphors [of legal discourse] truly do constrain our understanding of texts or our vision of political possibilities, how can doctrine be perceived as indeterminate?"117 If the indeterminacy thesis is true, then legal reification does not

11 Unger, 96 Harv. L. Rev. at 597-600 (cited in note 106).

114 Singer, 94 Yale L. J. at 53 (cited in note 6).

${ }^{115}$ For the classical discussion in which equity is seen as a supplement to the rule of law, see Aristotle, 10 Nicomachean Ethics (Martin Oswald trans. 1962). Critical scholars' advocacy of equity as superior to the rule of law was anticipated by Theodor Adorno, a critical theorist of the Frankfurt School. See Theodor W. Adorno, Negative Dialectics 31011 (E. B. Ashton trans. 1973).

116 See Gabel and Harris, 11 N.Y.U. Rev. L. \& Soc. Change at 374 (cited in note 30) (discussing delegitimation strategy).

${ }^{117}$ Boyle, $133 \mathrm{U}$. Pa. L. Rev, at 727 (cited in note 6) (original emphasis). 
produce the practical ill of bad outcomes in particular cases. Thus, while Gary Peller takes great pains to make it clear that the reification of the public and private spheres, which he argues pervaded legal discourse in the Lochner era, did not actually determine the result in any of the cases that struck down reformist legislation impinging on the liberty of contract, ${ }^{118}$ it is not clear what effect, if any, Peller believes the phenomenon he describes did have.

If the mystification thesis were weakened so as to be compatible with the indeterminacy thesis, its critical bite would also be weakened. The evil of mystification would produce only false consciousness, not bad decisions. In response, it could be argued that the false consciousness that results from legal mystification prevents the mobilization of change from outside the judicial system. But this will be hard to prove. As Jay Feinman has observed, "People must be aware of ideology if it is to serve as an effective legitimation device. The penetration of contract law doctrines into society is not great; first-year law students' common ignorance of its principles is annual evidence of this." 119 Indeed, one of the few ways that lay actors do learn about the legal system is through decisions in particular cases. If these decisions fail to convey the ideological message of legal discourse, then legal ideology is not likely to be transmitted to the culture at large. Arguments can be made about the effect of legal doctrine on elite groups, but if the indeterminacy thesis is true, the ill effects of legal ideology on society as a whole would appear to be quite modest.

Finally, the strongest versions of the indeterminacy thesis appear to undermine any attempt to articulate a vision of a more humane society, even one without laws. As Spann admits, "[A]ny proposal for a constructive program is doomed to failure. Because any proposal can be deconstructed, no proposal can ever command the respect of those who insist on principled justification as a prerequisite to action."120

By contrast, the mystification thesis without the indeterminacy thesis could be quite powerful as a tool of delegitimation. If false assumptions that contingent social phenomena are natural did determine results in particular cases, that fact would provide a strong motivation for change of legal practice. If more progressive doctrine can produce more humane decisions, then there is a good reason to change the law.

118 Peller, 73 Cal. L. Rev. at 1206, 1210 n.125 (cited in note 6).

119 Feinman, 30 U.C.L.A. L. Rev. at 853 (cited in note 15).

${ }^{130}$ Spann, 68 Minn. L. Rev. at 541 (cited in note 11). 


\section{Conclusion}

All this is not to say that the idea of indeterminacy is unimportant. Critical scholars, like those who preceded them-the realists, sophisticated positivists such as H.L.A. Hart, and even rights theorists such as Dworkin-are right to identify significant zones of underdetermination and contingency in legal doctrine. This modest version of the thesis can be pressed honestly and productively and, to the extent the polity is unaware of this state of affairs, perhaps it should be pressed. As a matter of political strategy, the claim that a large number of cases presented to judges are underdetermined may have a delegitimizing effect. Indeed, one strategy of the political right in the United States has been to call attention to the political nature of decisions made by the Warren Court and the California Supreme Court in order to delegitimize the courts and thereby undercut liberal reforms. Perhaps critical scholars are right to join the reactionaries in this regard. But delegitimizing the courts should not carelessly be equated with delegitimizing the liberal state. Indeed, it is at least possible that quite the opposite is true: delegitimizing the judiciary might have the effect of increasing the legitimacy of other institutions of the liberal state, such as bureaucracies and legislatures, that may possess a greater potential than courts to become instruments of repression.

Without a notion of the possibility of change, no theory of law can claim to be truly critical. As the critical scholar Alan Freeman put it, "The point of delegitimation is to expose possibilities more truly expressing reality, possibilities of fashioning a future that might at least partially realize a substantive notion of justice."121 The indeterminacy thesis does not have a significant role to play in that enterprise. Critical scholars should put away the dogma of indeterminacy, and try their hands at tasks more difficult than deconstruction. We must imagine a progressive and humane social order, and we must imagine a way to get there from here.

${ }^{121}$ Alan D. Freeman, Truth and Mystification in Legal Scholarship, 90 Yale L. J. 1229, 1230 (1981). 